\title{
Central European Journal of Communication 10 years on
}

DOI: 10.19195/1899-5101.11.2(21).1

It was in the Summer of 2008 when we were working on the very first issue of the Central European Journal of Communication (CEJC). Referencing findings from the international media conference "Comparing Media Systems: West Meets East" which took place in April 2007, we invited eleven contributors to submit their conference papers to open up the floor for a Journal created by the Polish Communication Association (PCA). The publication of the Fall 2008 issue of the CEJC was followed by several meetings with editors and staff from the University of Wrocław Press. On top of the discussed subjects, which were mostly related to review processes, ethical standards, the Journal's management, layout, submission processes, and the creation of the international Editorial Board, we wanted to be sure that the Journal meets the high-quality standards of publication. Overall, we felt that the time was critical for studies on media and communications in Central and Eastern Europe (CEE) to move forward. Our efforts went in line with institutionalization of the newly-created PCA and actions related to the autonomy of media and communications studies in Poland, which led to the success back in 2011. On an international level the goal has always been to act as a platform where scholars from Western-developed European countries can exchange their work with colleagues from CEE. Finally, as social media and other media-like services (search engines, content aggregators, user-generated media and so on) were becoming more and more popular in 2008 and onwards, we were sure that the Journal has the potential to cover all the rapid developments of the media and information society which were still to come.

Today, as we celebrate the $10^{\text {th }}$ Anniversary of the Central European Journal of Communication, we are happy to share with you our "Thank You" alongside some of our achievements.

We would like to thank scholars and practitioners who accepted our invitation to join the CEJC's Editorial Board. We thank you for your involvement in the review processes and efforts to spread the news about CEJC and its international presence. We also thank all the guest editors and reviewers who agreed to work with us over the last ten years. Our special thank you goes to Irena Szymaniec, Agnieszka Majewska, Barbara Kaczmarek, Marzena Golisz, Agnieszka Madyńska, Monika Mielcarek from the University of Wrocław Press and the publisher's native speaker 
editor - Stephen Marlborough, who supported the Journal at the early stage of its publishing. We also remember our CEJC staff, scholars, and PhD students who took care of submission and review processes, book reviews and the presence of the CEJC online as Dorota Piontek, Paweł Baranowski, Jacek Nożewski, and Adam Michel. Today, Róża Norström (Smolak), Paulina Barczyszyn-Madziarz, and Julia Trzcińska work in the team. Above all, we thank all the authors who agreed to undertake their research, reviews, and interviews with media scholars published via the Central European Journal of Communication.

\section{PUBLICATIONS AND AUTHORS}

Thanks to you we are proud to summarise the first 10 years of the publishing of the CEJC with the following numbers; in the period of 2008-2018, a total of 164 articles written by 242 authors from 32 different countries were published. This includes the number of book reviews and interviews with experts in related media fields (see Figure 1 and Table 1).

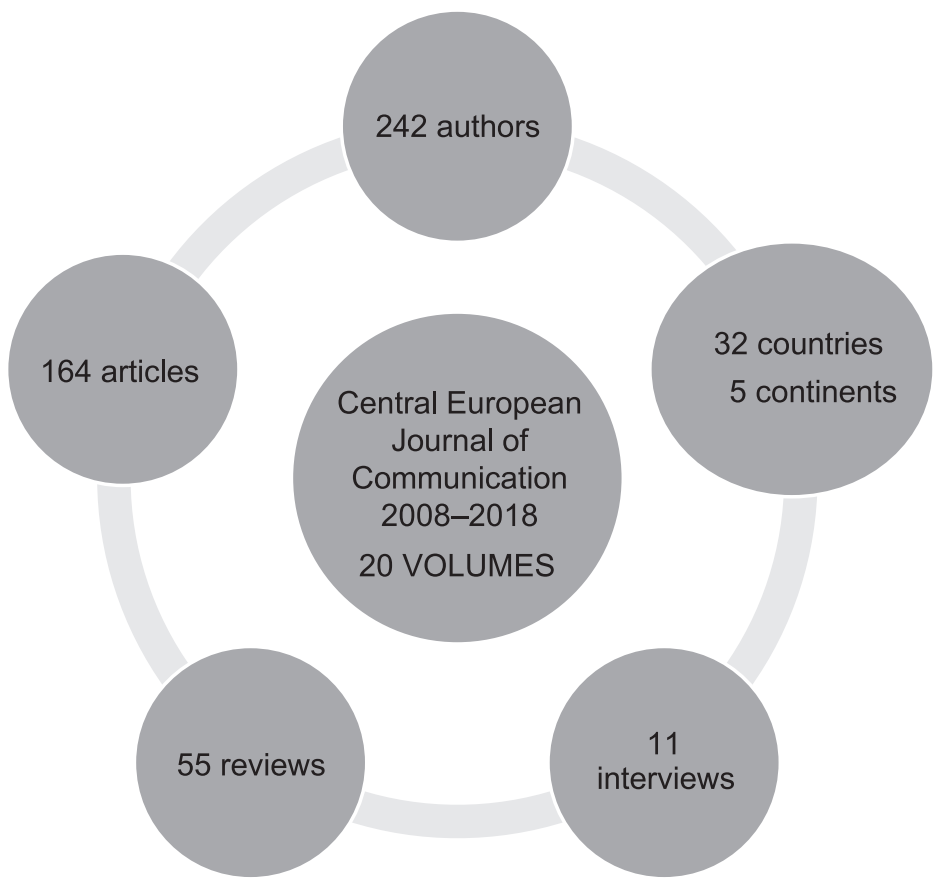

Figure 1. Central European Journal of Communication in numbers (2008-2018)

Our database indicates that, among the 164 articles published from Fall 2008 to Spring 2018, 52 authors were associated with Polish universities. Looking at the number of authors' country association: 27 colleagues represented the USA, and 8 authors were from the following countries: Estonia, Germany, and Hungary (see Figure 2). 
Editorial

Table 1. The list of published volumes

\begin{tabular}{|c|c|c|c|c|c|c|}
\hline Year & $\begin{array}{l}\text { No of } \\
\text { volume }\end{array}$ & Editors & Guest editors & $\begin{array}{l}\text { No of } \\
\text { articles }\end{array}$ & $\begin{array}{c}\text { No of } \\
\text { reviews }\end{array}$ & Interviews \\
\hline $1 / 2008$ & $\begin{array}{l}1 \\
\text { Fall }\end{array}$ & - & $\begin{array}{l}\text { Michał Jacuński } \\
\text { (Poland) }\end{array}$ & 10 & - & - \\
\hline \multirow{2}{*}{$2 / 2009$} & $\begin{array}{l}2 \\
\text { Spring }\end{array}$ & $\begin{array}{l}\text { Bogusława Dobek- } \\
\text {-Ostrowska }\end{array}$ & $\begin{array}{l}\text { Karol Jakubowicz } \\
\text { (Poland) }\end{array}$ & 11 & - & - \\
\hline & $\begin{array}{l}3 \\
\text { Fall }\end{array}$ & $\begin{array}{l}\text { Bogusława Dobek- } \\
\text {-Ostrowska }\end{array}$ & - & 12 & - & - \\
\hline \multirow[b]{2}{*}{$3 / 2010$} & $\begin{array}{l}4 \\
\text { Spring }\end{array}$ & Michał Głowacki & Lars Nord (Sweden) & 9 & - & - \\
\hline & $\begin{array}{l}5 \\
\text { Fall }\end{array}$ & - & $\begin{array}{l}\text { Wayne Wanta } \\
\text { (USA), Bartłomiej } \\
\text { Łódzki (Poland) }\end{array}$ & 9 & - & - \\
\hline \multirow[b]{2}{*}{$4 / 2011$} & $\begin{array}{l}6 \\
\text { Spring } \\
\end{array}$ & - & $\begin{array}{l}\text { Jerzy Olędzki } \\
\text { (Poland) }\end{array}$ & 10 & - & - \\
\hline & $\begin{array}{l}7 \\
\text { Fall }\end{array}$ & $\begin{array}{l}\text { Bogusława Dobek- } \\
\text {-Ostrowska }\end{array}$ & $\begin{array}{l}\text { Barbara Pfetsch } \\
\text { (Germany) }\end{array}$ & 7 & 6 & $\begin{array}{l}\text { Daniel C. Hallin } \\
\text { (USA), Paolo } \\
\text { Mancini (Italy) }\end{array}$ \\
\hline \multirow[t]{2}{*}{$5 / 2012$} & $\begin{array}{l}8 \\
\text { Spring }\end{array}$ & Michał Głowacki & $\begin{array}{l}\text { Auksė Balčytíné } \\
\text { (Lithuania) }\end{array}$ & 8 & 5 & $\begin{array}{l}\text { Karol } \\
\text { Jakubowicz } \\
\text { (Poland) }\end{array}$ \\
\hline & $\begin{array}{l}9 \\
\text { Fall }\end{array}$ & - & $\begin{array}{l}\text { Epp Lauk (Estonia), } \\
\text { Michał Kuś (Poland) }\end{array}$ & 7 & 2 & $\begin{array}{l}\text { Stephan Russ- } \\
\text {-Mohl (Swiss) }\end{array}$ \\
\hline \multirow{2}{*}{$6 / 2013$} & $\begin{array}{l}10 \\
\text { Spring }\end{array}$ & $\begin{array}{l}\text { Bogusława Dobek- } \\
\text {-Ostrowska }\end{array}$ & Peter Gross (USA & 8 & 5 & $\begin{array}{l}\text { Jane Curry } \\
\text { (USA) }\end{array}$ \\
\hline & $\begin{array}{l}11 \\
\text { Fall }\end{array}$ & Michał Głowacki & - & 9 & 5 & - \\
\hline \multirow[b]{2}{*}{$7 / 2014$} & $\begin{array}{l}12 \\
\text { Spring }\end{array}$ & $\begin{array}{l}\text { Bogusława Dobek- } \\
\text {-Ostrowska }\end{array}$ & $\begin{array}{l}\text { Gianpietro } \\
\text { Mazzoleni (Italy) }\end{array}$ & 8 & 5 & $\begin{array}{l}\text { Walery Pisarek } \\
\text { (Poland) }\end{array}$ \\
\hline & $\begin{array}{l}13 \\
\text { Fall }\end{array}$ & Michał Głowacki & $\begin{array}{l}\text { Norbert Merkovity } \\
\text { (Hungary), } \\
\text { Dominic Wring } \\
\text { (Great Britain) }\end{array}$ & 7 & 3 & $\begin{array}{l}\text { Peter Gross } \\
\text { (USA) }\end{array}$ \\
\hline \multirow[b]{2}{*}{$8 / 2015$} & $\begin{array}{l}14 \\
\text { Spring }\end{array}$ & Michał Głowacki & $\begin{array}{l}\text { Romy Wöhler } \\
\text { (Austria) }\end{array}$ & 8 & 4 & $\begin{array}{l}\text { Andrei Richter } \\
\text { (Russia) }\end{array}$ \\
\hline & $\begin{array}{l}15 \\
\text { Fall }\end{array}$ & $\begin{array}{l}\text { Bogusława Dobek- } \\
\text {-Ostrowska, Róża } \\
\text { Smolak }\end{array}$ & $\begin{array}{l}\text { Zrinjka Peruško } \\
\text { (Croatia) }\end{array}$ & 8 & 3 & $\begin{array}{l}\text { Maxwell } \\
\text { McCombs } \\
\text { (USA) }\end{array}$ \\
\hline \multirow[t]{2}{*}{$9 / 2016$} & $\begin{array}{l}16 \\
\text { Spring }\end{array}$ & $\begin{array}{l}\text { Bogusława Dobek- } \\
\text {-Ostrowska, Adam } \\
\text { Michel }\end{array}$ & David Weaver (USA) & 8 & 6 & $\begin{array}{l}\text { David H. } \\
\text { Weaver (USA) }\end{array}$ \\
\hline & $\begin{array}{l}17 \\
\text { Fall }\end{array}$ & $\begin{array}{l}\text { Michał Głowacki, } \\
\text { Jacek Nożewski }\end{array}$ & $\begin{array}{l}\text { Gunnar Nygren } \\
\text { (Sweden) }\end{array}$ & 6 & 4 & - \\
\hline
\end{tabular}




\begin{tabular}{|c|l|l|l|c|c|l|}
\hline \multirow{2}{*}{$10 / 2017$} & $\begin{array}{l}18 \\
\text { Spring }\end{array}$ & $\begin{array}{l}\text { Bogusława Dobek- } \\
\text {-Ostrowska, Julia } \\
\text { Trzcińska }\end{array}$ & - & 7 & 4 & $\begin{array}{l}\text { Jesper } \\
\text { Strombäck }\end{array}$ \\
\cline { 2 - 7 } & $\begin{array}{l}19 \\
\text { Fall }\end{array}$ & $\begin{array}{l}\text { Michał Głowacki, } \\
\text { Róża Smolak }\end{array}$ & - & 6 & 1 & - \\
\hline $11 / 2018$ & $\begin{array}{l}20 \\
\text { Spring }\end{array}$ & $\begin{array}{l}\text { Bogusława Dobek- } \\
\text {-Ostrowska, Adam } \\
\text { Michel }\end{array}$ & - & 6 & 2 & $\begin{array}{l}\text { Christina Holtz- } \\
\text {-Bacha }\end{array}$ \\
\hline
\end{tabular}

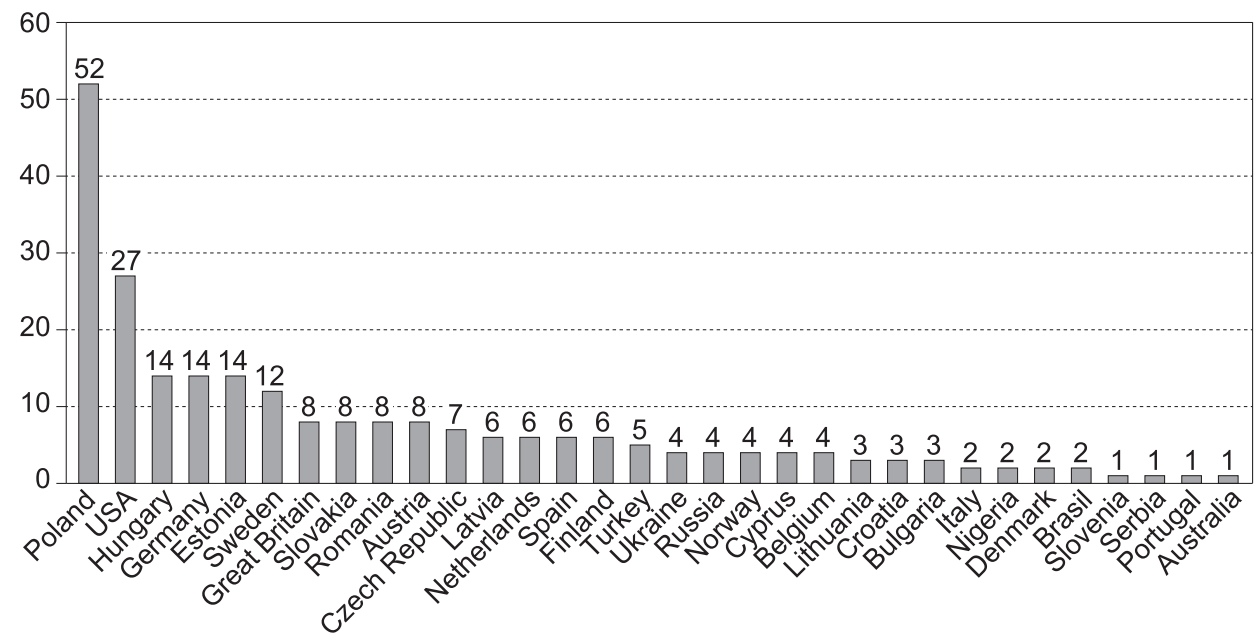

Figure 2. Authors in numbers (2008-2018)

So far 11 interviews have been conducted. Among the interviewees were Prof. Daniel C. Hallin and Prof. P. Mancini - creators of three models of media systems - Prof. Walery Pisarek, and the authors of the agenda setting theories - Prof. Maxwell McCombs and Prof. David H. Weaver. From the Spring 2016 issue, each reviewed scientific article has a DOI - digital ID, which is used by all recognized and prestigious scientific publications in the world. Some 55 reviews of important new releases - published in the previous two years - have also been published.

International collaboration has also been important for us when creating more formal networks, such as CEECOM established in 2012 in Prague (followed by the tradition of Central and Eastern European conferences in Książ, Telc/Brno, Bratislava, and Cracow). Through the calendar of international conferences and events, Spring issues were promoted at the annual conferences of the International Communication Association (in Chicago 2009, Singapore 2010, Boston 2011, Phoenix 2012, London 2013, Seattle 2014, San Juan 2015, Fukuoka 2016, San Diego 2017, and Prague 2018), while Fall issued at the congresses of the Polish Communication Association (in Wrocław 2008, Lublin 2010, Cracow 2013, and Poznań 2016). ECREA's CEE-Network has further made collaboration of CEE Journals one of its main goals 
in the period 2012-2014. As a result, the CEE Journal database of media and communication publications from Central and Eastern Europe was presented at the CEECOM conference in Wrocław (2014). Panel discussion attended by journal editors from Lithuania, Russia, Serbia, Slovakia, Bulgaria, and Romania indicated challenges for scientific journals' development, such as internationalization, financial support, citation, and indexation.

\section{SCIENTIFIC DATABASE}

As the latter was critical we successfully submitted to several scientific indexes/ databases:

- H Index Communication Journals

- Google Scholar Metrics (in 2014, the journal took 281st position in the international ranking of 434 journals on communication and after the Slovenian journal Javnost occupied second position among journals from Central and Eastern Europe)

- Index Copernicus Journals Master List ICV (where the ICV indicator in 2014 was 95.18 and the standardized value was 7.77)

- The European Reference Index for Humanities and Social Sciences (ERIH PLUS)

- The Central and Eastern European Online Library (CEEOL)

- The Central European Journal of Social Sciences and Humanities - CEJSH

- Emerging Sources Citation Index registered by Thompson Reuters

- EBSCO host Connection

- BAZHUM - database of humanities and social sciences journals

- Scopus database.

The CEJC is on the list of scientific journals by the Ministry of Science and Higher Education. Affiliation to these type of platforms allows us to reach a wide audience and enables us to promote the journal internationally. The CEJC is also available in free access mode on the journal's website.

\section{WEBSITE OF THE JOURNAL WWW.CEJC.PTKS.PL}

The website is a tool supporting the editorial office. It allows promotion of publishing activity and informs about scientific events in which the editorial office participates. The basis of the online platform is a list of issues of the journal published every six months in free access mode. All previously published and catalogued volumes are available on the website database (from Fall 2008 to Spring 2018). Additionally, users are regularly informed about the recruitment of texts for subsequent issues and have the option of sending their paper through a speciallycreated electronic submission form. On the website you can find basic information about the editorial office, information on belonging to databases and rules related to the process of reviewing submitted articles. 
$2008-2018$

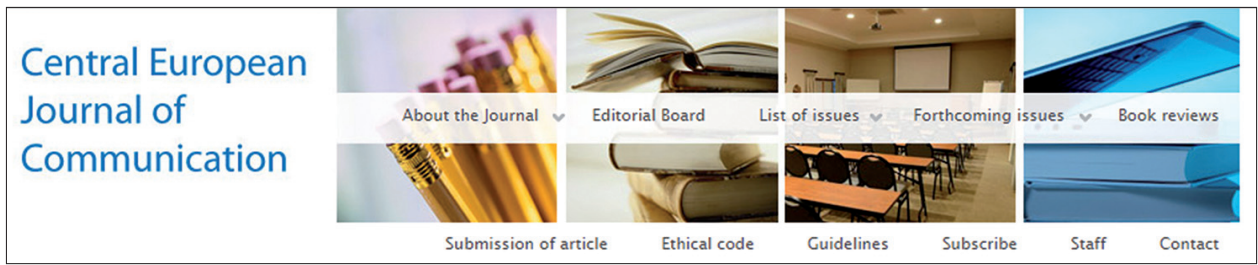

Since 2018

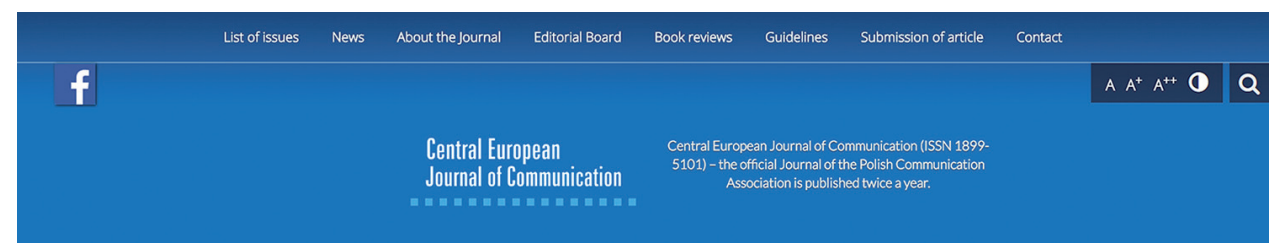

Very important in this context is also the part, in which there is an ethical code which should be followed by authors, reviewers, and editors. By starting the system of electronic submission of articles directly from the website, it was also decided to include guidelines related to editing requirements, which was reflected in a separate tab.

The website is regularly updated, therefore one of the permanent elements of the portal has become a news section, which provides the latest, selected information about participation in events, the publication of a new volume, and others. The website is also supported by activity in social media. Posts placed there redirect the user to the home page of the journal.

In the next academic year, it is planned to extend the activities of the editorial office in social media and to attach a greater emphasis on the distribution and promotion of materials through this channel. The website will be further equipped with interactive elements, which assumedly will have to improve communication between the editorial team and the user and increase the level of interactivity between them.

Information on current events is also published in newsletters of the ICA, ECREA, IFCA, and on the social network.

\section{SOCIAL MEDIA WWW.FACEBOOK.COM/CEJCPTKS}

The journal has an account on social media and is observed by 809 users. The platform provides information on the recruitment of texts, new publications, various types of events, and interesting articles or projects. Currently, the Polish Communication Association and CEJC use one common account. For this reason, in the next academic year it is planned to set up a separate profile, which will focus only on the work of the editorial office. 
We are also happy to inform you that our new www.cejc.ptks.pl website has just been launched; please be informed about the call for papers, submission processes, and all the CEJC articles free available online. This also relates to the current issue with publications from Poland, Hungary, Germany, Sweden, and Croatia.

And last, but not least, thank you to all our readers,

The CEJC Team 2018

Bogusława Dobek-Ostrowska Editor-in-chief

Michał Głowacki

Executive Editor

Julia Trzcińska

Book Review Editor

Róża Norström (Smolak)

Coordinator of submission

Paulina Barczyszyn-Madziarz

Coordinator of the database 